Trinity University

Digital Commons @ Trinity

Human Communication and Theatre Faculty

Research

Human Communication and Theatre

$7-2021$

\title{
The Theatre Industry's Essential Workers: Catalysts for Change
}

Nathan Stith

Trinity University, nstith@trinity.edu

Aria Gastón-Panthaki

Trinity University, agastonp@trinity.edu

Rachel Morris

Trinity University, rmorris@trinity.edu

Follow this and additional works at: https://digitalcommons.trinity.edu/hct_faculty

Part of the Theatre and Performance Studies Commons

\section{Repository Citation}

Stith, N., Gastón-Panthaki, A., \& Morris, R. (2021). The theatre industry's essential workers: Catalysts for change. Theatre Topics, 31(2), 73-86. http://doi.org/10.1353/tt.2021.0023

This Article is brought to you for free and open access by the Human Communication and Theatre at Digital Commons@ Trinity. It has been accepted for inclusion in Human Communication and Theatre Faculty Research by an authorized administrator of Digital Commons @ Trinity. For more information, please contact jcostanz@trinity.edu. 


\title{
The Theatre Industry's Essential Workers: Catalysts for Change
}

\author{
Nathan Stith, Aria Gastón-Panthaki, and Rachel Morris
}

On January 22, 2020, the first confirmed case of COVID-19 was reported in the United States (Stokes et al.). Within weeks, the virus was spreading across the country, impacting every aspect of life. On March 12, Broadway theatre producers announced a temporary closure, which has been extended through at least June 2021 (Paulson "Broadway"). Soon after, theatres of all kinds throughout the country closed indefinitely. As theatre scholars and artists, our research team was immediately struck by the tremendous impact these closures would have on theatre artists from around the country. Using a mixture of qualitative and quantitative methods, we sought to gain a deeper understanding of how the COVID-19 closures were affecting the perspectives of theatre professionals. In this essay, we present the results of that research, highlighting possible strategies for a post-pandemic future that we gained from speaking with theatre's essential workers.

\section{A Review of the Literature}

Surprisingly, we found very little information regarding the impact of previous pandemics on the theatre industry. However, an abundance of relevant materials was available in nonacademic periodicals focused on the current pandemic's impact on the future of the theatre industry. During the late spring and early summer of 2020 , these sources generally fell into two categories: 1 ) articles that provided data from surveys given to theatre audiences; and 2) ideas, thoughts, and opinions from prominent theatre professionals (mostly Broadway artists) about the impact COVID-19 was having on their careers and their hopes for the future of the industry.

The first category of relevant literature focused on gauging the opinions of regular theatregoers regarding their feelings about returning to theatre spaces. A May 11, 2020 article in American Theatre examined two recent surveys of New York City and national theatre audiences. The survey found that the majority of theatregoers in New York City and nationwide intended to wait for between three-to-six months after theatres reopen before returning to them (Weinert-Kendt). A New York Times/Siena College Research Institute survey further revealed that the biggest concern among potential theatregoers was a lack of trust that other audience members would wear masks and adhere to social-distancing guidelines (Jacobs).

The available literature also focused primarily on the impact the pandemic was having on Broadway productions and artists of notoriety. For example, the Guardian published an interview with Broadway alum Simon Russell Beale (Thorpe), and Broadway icon Joel Grey published an opinion piece in the New York Times. Soon after the closure of Broadway theatres, a number of "what-could-have-been" articles appeared that examined yet-to-open Broadway productions such as Mrs. Doubtfire and Sing Street (Paulson "Universe”; Soloski). In addition to articles about Broadway shows and performers, the literature also included several articles like Charles McNulty's Los Angeles Times article titled, "25 Top Theater Minds Dream the Future: What Will the Post-Pandemic Stage Look Like?” In it, McNulty provides written responses from twenty-five artists to his email request 
to "imagine the future" of the industry. The article includes responses from prominent Broadway and regional theatre artists, including Tony winners Patti Lupone, Michael Cerveris, and Diane Paulus as well as Pulitzer winners Michael R. Jackson and Quiara Alegría Hudes.

The available literature reveals a hole in the current research; most pieces either focus primarily on audiences or else restrict input to the voices of well-known artists. What is missing is the perspective of theatre professionals who keep the industry churning at all levels, across the country. Thus our research — through a survey and individual interviews — seeks to give voice to a wider range of theatre professionals in order to share their ideas and thoughts about the future of our industry.

\section{Methods}

\section{Participants}

Participants included 553 theatre professionals ${ }^{1}$ with work experiences in all fifty states. They were recruited using a variety of tools, including surveys distributed through Facebook and Twitter, specific Facebook groups ${ }^{2}$ and direct emails to industry colleagues. The team used snowball-sampling techniques, a nonprobability sampling method in which existing participants recruit future participants. ${ }^{3}$ Table 1 provides demographic information of the participants, including years of professional theatre experience, type of work, union membership, type of theatre, occupations, race, gender, sexuality, and employment/income impact due to COVID-19.

\section{Data}

Our project aimed to collect data from theatre professionals across the United States concerning their hopes and fears for the future of the industry post-quarantine shutdowns. Using the literature review, we extracted themes from what theatre professionals of notoriety were discussing to create a survey. After receiving institutional review board approval, the survey was released to theatre professionals across the country through Facebook, Twitter, and personal emails. Using Qualtrics, the data was safely stored and participants were allowed to remain anonymous.

Each participant in the survey was given the option to be contacted via email to participate in our interview process. The decision was made to go from survey questions to interviews, because it was concluded that the research would benefit from more in-depth perspectives from theatre professionals. After analyzing preliminary survey data, the research team concluded that a shift in focus would be beneficial in the interview process, where the emphasis would be less on individual "hopes and fears" related to one's artistic career and more on systemic changes that the participants wished to see once the industry returned to "normal." Our team had an allotted a two-month period to interview participants. Of these 209 survey participants who expressed interest in being interviewed, eighty-one responded to the emails sent by the research team to set up the interviews. These participants were individually interviewed by a member of our team using an outline of questions focused on the individual's views on the changes that they would like to see within the theatre industry and their concerns for how the industry would return post-quarantine. Eleven questions were asked to all interviewees, plus an additional question if a participant had lost work. The participants were then asked a few tailored questions that were specific to their primary job title. At the end of each interview, the interviewee completed a consent form to allow the researchers to use the participant's name.

Once the interviews were completed the research team began coding. Using thematic analyses to divide the categories, researchers reviewed each interviews' transcript and coded the common topics that the individuals discussed. 
Table 1. Survey Participant's Years of Professional Theatre Experience, Type of Work, Unions, Type of Theatre, Occupations, Race, Gender, Sexuality, and Employment/Income Impact Due to COVID-19.

\begin{tabular}{|c|c|c|}
\hline \multirow[b]{2}{*}{ Characteristics } & \multicolumn{2}{|c|}{$\begin{array}{c}\text { Total Sample } \\
(N=553)\end{array}$} \\
\hline & $n$ & $\%$ \\
\hline \multicolumn{3}{|l|}{ Years of Professional Theatre Experience } \\
\hline $0-5$ years & 99 & 18 \\
\hline $5-10$ years & 109 & 20 \\
\hline $10-15$ years & 80 & 14 \\
\hline $15-20$ years & 69 & 13 \\
\hline $20-25$ years & 73 & 13 \\
\hline $25-30$ years & 46 & 8 \\
\hline over 30 years & 75 & 14 \\
\hline \multicolumn{3}{|l|}{ Type of Work } \\
\hline Freelance & 233 & 42 \\
\hline Full-Time & 134 & 25 \\
\hline Both & 179 & 33 \\
\hline \multicolumn{3}{|l|}{ Unions } \\
\hline Union & 270 & 49 \\
\hline Non-Union & 268 & 48 \\
\hline Prefer not to say & 15 & 3 \\
\hline \multicolumn{3}{|l|}{ Types of Theatre* } \\
\hline Union & 120 & 22 \\
\hline Non-Union & 195 & 35 \\
\hline Regional & 316 & 57 \\
\hline Local/Community & 176 & 32 \\
\hline Off-Broadway/Off-Off-Broadway & 108 & 20 \\
\hline \multicolumn{3}{|l|}{ Occupations* } \\
\hline Performer & 210 & 38 \\
\hline Other & 169 & 31 \\
\hline Director & 153 & 28 \\
\hline Stage Manager & 150 & 27 \\
\hline Technician/Backstage Crew & 140 & 25 \\
\hline Producer & 91 & 16 \\
\hline Artistic Director & 53 & 10 \\
\hline Playwright & 53 & 10 \\
\hline Lighting Designer & 49 & 9 \\
\hline Scenic Designer & 35 & 6 \\
\hline Choreographer & 29 & 5 \\
\hline Costume Designer & 28 & 5 \\
\hline Sound Designer & 27 & 5 \\
\hline \multicolumn{3}{|l|}{ Race $^{*}$} \\
\hline Asian & 10 & 2 \\
\hline Black/African & 14 & 3 \\
\hline Caucasian & 476 & 86 \\
\hline Hispanic/Latinx & 50 & 9 \\
\hline Native American & 7 & 1 \\
\hline Pacific Islander & 3 & 0.5 \\
\hline Other & 14 & 3 \\
\hline Prefer not to Answer & 23 & 4 \\
\hline
\end{tabular}


Table 1, continued.

\begin{tabular}{|c|c|c|}
\hline \multirow[b]{2}{*}{ Characteristics } & \multicolumn{2}{|c|}{$\begin{array}{l}\text { Total Sample } \\
(N=553)\end{array}$} \\
\hline & $n$ & $\%$ \\
\hline \multicolumn{3}{|l|}{ Gender+ } \\
\hline Woman & 348 & 64 \\
\hline Man & 173 & 32 \\
\hline Non-Binary & 11 & 2 \\
\hline Prefer Not to Say & 14 & 3 \\
\hline \multicolumn{3}{|l|}{ Sexuality } \\
\hline Asexual & 12 & 2 \\
\hline Bisexual & 78 & 14 \\
\hline Gay/Lesbian & 71 & 13 \\
\hline Heterosexual & 317 & 58 \\
\hline Pansexual & 17 & 3 \\
\hline Queer & 22 & 4 \\
\hline Other & 4 & 1 \\
\hline Prefer Not to say & 30 & 5 \\
\hline \multicolumn{3}{|c|}{ Employment/Income Impact Due to COVID-19* } \\
\hline Not At All & 38 & 7 \\
\hline Furlough & 155 & 28 \\
\hline Inability to Seek New Income & 306 & 55 \\
\hline Loss of Income & 381 & 69 \\
\hline Salary Reduction & 56 & 10 \\
\hline Other & 67 & 12 \\
\hline \multicolumn{3}{|l|}{ States*\# } \\
\hline New York & 190 & 34 \\
\hline Washington & 112 & 20 \\
\hline California & 71 & 13 \\
\hline Florida & 67 & 12 \\
\hline Colorado & 61 & 11 \\
\hline \multicolumn{3}{|c|}{$\begin{array}{l}\text { * Indicates categories where participants were able to select more than one option. } \\
\text { +We used three of the most commonly adopted gender identities "Woman, Man, and Non-Binary" rather } \\
\text { than asking for participants sex (i.e. female/male). } \\
\text { \# We received survey responses from people who have worked in all fifty states during the past two years. } \\
\text { This table includes the five most commonly selected states. }\end{array}$} \\
\hline
\end{tabular}

\section{Limitations}

As with most mixed-method research, there were limitations to the study. Regarding our demographics, there was a skew toward performers; however, 88 percent of the participants who selected "performer" also selected at least one other job in theatre. There was also a slight skew toward participants having had worked in New York City during the past two years. This skew represents the high number of theatre professionals based there. The participant pool also had considerably more women than men. Finally, "Caucasian" was the most selected race in our survey, with a considerable skew. This "white skew" is one of the problems this essay addresses regarding the racial makeup of the theatre industry (fig. 1). 


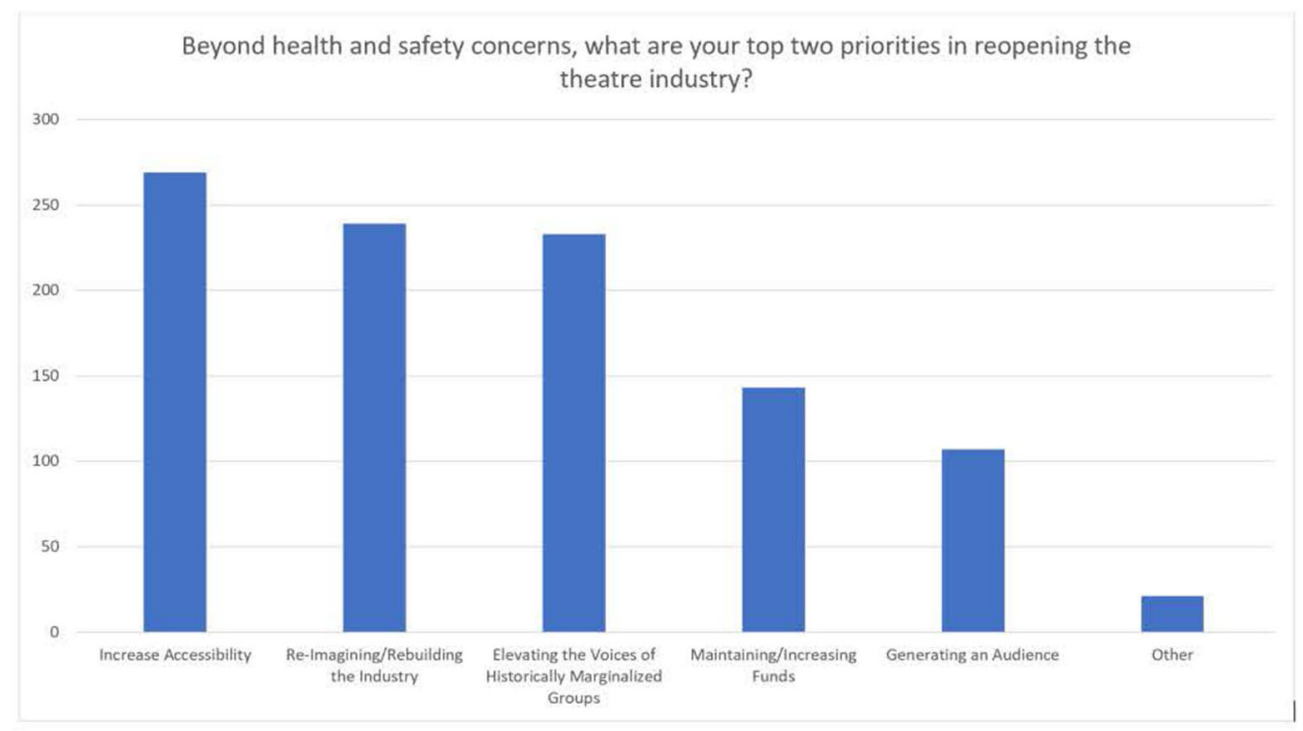

FIG. 1 Top priorities in reopening the theatre industry.

\section{Results}

Beyond gathering a demographic breakdown, we asked our survey respondents three central questions in an effort to understand how theatre professionals from across the country were feeling about the theatre closures. For each question, survey respondents could choose multiple options. When asked "Beyond health and safety concerns, what are your top two priorities in reopening the theatre industry? 49 percent of our survey respondents identified "Increasing accessibility" as one of their two priorities; 43 percent selected "Re-imagining/rebuilding the industry" as one of their main concerns; and 42 percent selected "Elevating the voices of historically marginalized groups."

Similar topics were identified by the individuals who participated in our in-depth interviews: 58 percent noted a desire to make theatre more accessible both for audiences and theatre professionals; 50 percent discussed economic gatekeeping in educational and internship opportunities, which prevents many low-income candidates from finding success in the industry; 26 percent mentioned their desire for theatres to connect more with diverse communities. Ninety-three percent of our interviewees noted that theatres should be seeking out diverse individuals when hiring for any and all positions in their organization. Within that 93 percent, three approaches to increasing diversity were most often identified: 65 percent noted a desire for increasing gender and racial diversity on boards and in executive leadership positions; 30 percent described a need to increase all hiring opportunities for women, nonbinary, transgender, and differently abled individuals; and 28 percent said they would like to see an increased use of colorblind, color-conscious, and nontraditional casting (fig. 2). ${ }^{4}$

Responding to the question "As a theatre professional, what is the greatest cultural value of theatre?" 64 percent of survey participants chose "Assembly/shared experience" as one of their top three selections. The two most commonly chosen options following this were "Exposure to diverse ideologies and cultures" at 56 percent and "Empathetic growth" at 56 percent. Similarly, 70 percent of our interviewees expressed a desire for theatrical productions that both educate and challenge their audiences. Moreover, 51 percent also noted their hope for more social and political theatre that relates directly to current social issues, engages with the public, and empowers the communities that need it most (fig. 3).

When our survey asked "How do you think theatre professionals should be using this 'pause'”? 73 percent of the participants selected "Re-imagining the industry" as one of their three choices. 


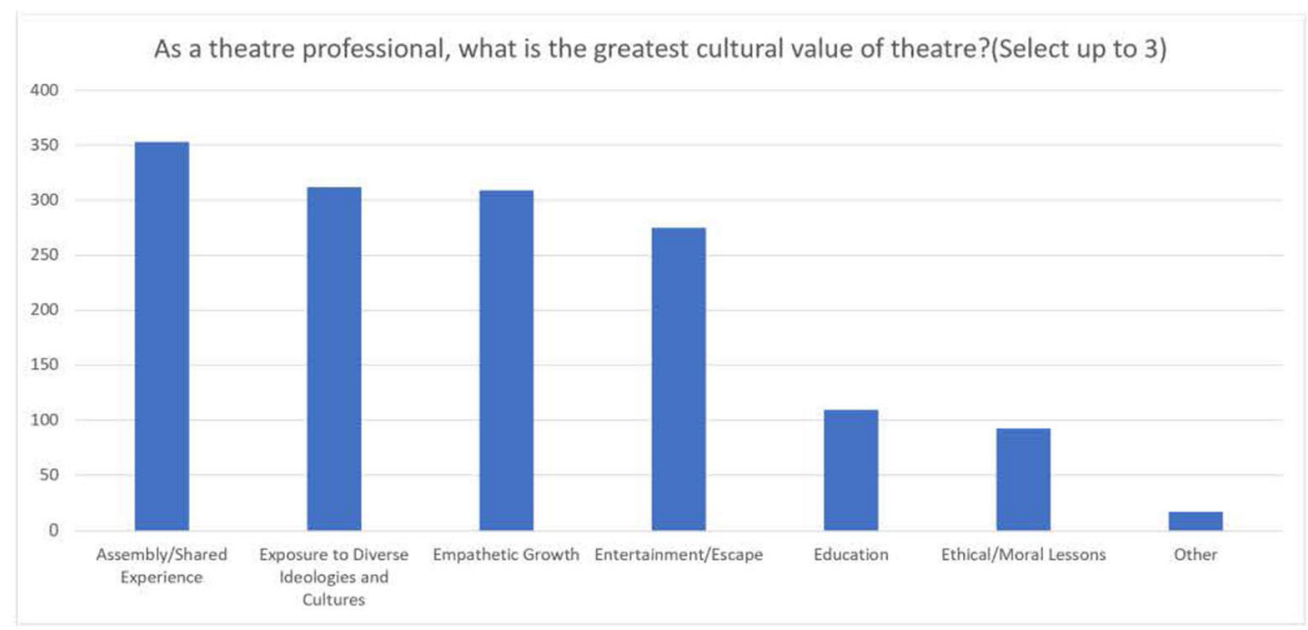

FIG. 2 The cultural value of theatre.

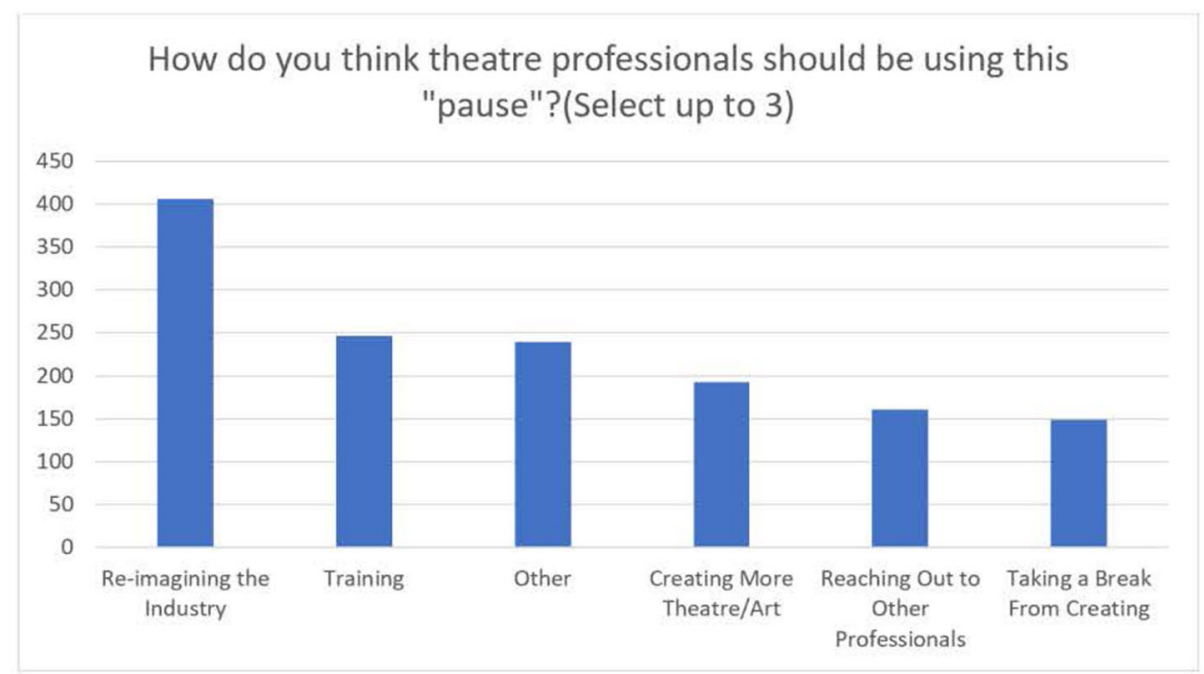

FIG. 3 How should theatre professionals be using this "pause"?

When asked about reimagining the industry, 45 percent noted a concern that there would be an increase in "safe"/traditional shows being produced following the pandemic; and 60 percent of our interviewees mentioned a desire for theatre professionals to call out theatres that do not make good on promises to make their companies more accessible and to put an end to the oppression and discrimination of marginalized groups within their organizations.

\section{Analysis and Discussion}

After reviewing the literature focused on well-known artists and their views on the impact of COVID-19 on our industry, our research team set out to amplify the voices of a broader spectrum of theatre professionals from around the country. The initial goal of the survey was to understand the current state of mind of these theatre professionals during the pandemic. From the survey responses, we realized that, as a reseatrch team, we had overlooked the significant systemic structures of oppression that have embedded themselves throughout the profession. This theme in the survey data, along with the murders of George Floyd and Breonna Taylor and the resulting country-wide 
protests in support of Black Lives Matter during the summer of 2020 led our team to alter the content of our interviews. Rather than simply "taking the temperature" of theatre artists during the pandemic, we crafted the interview questions to allow professionals the opportunity to expand on how they wished the theatre industry to be reimagined. From the responses to both the survey and interviews, three key themes related to reimagining the industry by fighting systemic structures of oppression emerged: increasing audience accessibility; mindful season selection; and increasing diversity in hiring practices across our industry.

\section{Audience Accessibility}

In one interview, performer Nancy Blum said that "theatre right now . . . does seem to speak to kind of a selected audience or self-selected audience. . . I I hope it will change to be more inclusive of all kinds of people that are represented in this country. Also, if we want more people to go to [the] theatre, it's going to have to be more accessible, not just physically, but economically." 5 Prior audience studies for major theatres support Blum's concerns. A study investigating 500,000 audience members at twenty-five theatres in the San Francisco Bay Area between 2006 and 2012 revealed that audience members were 90 percent white, 65 percent college educated, and 60 percent male, with an average household income of $\$ 109,167$ (Lord 20). Similar theatregoer demographics can be found in cities across the country. What is especially troubling is that these demographic statistics do not represent the general public. Why is there such a disparity between the demographic breakdown of theatre audiences and the population at large?

One of the greatest barriers to accessibility for audiences is ticket prices. As these prices continue to rise, fewer people can afford to attend. ${ }^{6}$ In our interview with Emily Harrison, artistic director of Square Product Theatre in Boulder, Colorado, she noted the importance of making ticket prices affordable in order to increase accessibility, saying that "we have a goal . . to be as accessible as possible, because a lot of people in our community ... don't have a lot of expendable income... students, women, queer people, people of color . . . have been historically marginalized and therefore don't have the same kind of generational wealth to do things like go to theatre ... but they want to." In addition to keeping ticket prices lower, other theatres are finding unique ways to make their companies accessible to a wider audience. Elliott Bales, a performer and board member of Theater Alliance in Washington, D.C., discussed a creative solution to the issue of accessibility that his company employs:

We reserve 10 percent of all the seats in our house, every performance ... and anyone from our
community [can] come to this theatre an hour before and it's "name your own price" not "pay
what you can" ... that is a judgment of your ability to pay and we don't want to put [up] that
kind of barrier. But you tell me what it's worth to walk in here... . I've taken a paper clip, I've
taken a rubber band ... but frequently people who've come in and paid five dollars . . . have
walked out and left me twenty or twenty-five ... if the theatre is going to thrive ... the barriers
to participation ... have to be removed. And I am hopeful that that's what we're headed towards.

To increase accessibility and rethink audience demographics, several respondents argued, theatres must take a hard look into how they price their tickets and what creative options might be at their disposal. Many of our interviewees stressed the vital importance of creative pricing strategies. ${ }^{7}$ For example, a California-based director we spoke with said, "I think it's criminal that there are so many groups that ... are essentially ... shut out of theatre because it's just financially not accessible to them. . . . I think that it's just criminal." Financial barriers are one of the leading causes of the lack of diversity found in theatre audiences. Our findings suggest that if theatres wish to increase their accessibility, they must reexamine their ticketing models. 


\section{Season Selection}

When asked about the cultural value of theatre, 64 percent of our survey respondents selected "Assembly/shared experience" as one of their top three choices. The theatre's ability to bring people together has always been a defining characteristic, but within the context of a global pandemic in which theatres are closed, the desire to gather together and share an experience seems obvious. The next two most-common survey responses, "Exposure to diverse ideologies and cultures" (56 percent) and "Empathetic growth" (56 percent), connect to the second theme in the data: season selection that mindfully engages with diverse communities. A desire for theatres to connect with the diversity within their communities was noted by 26 percent of our interviewees, including Dennis Gromelski, executive director of FUSION Theatre Company in Albuquerque, New Mexico. According to him, FUSION has begun "developing full-length works from New Mexican stories and . . teaming up with New Mexican [artists].” These projects include a short-play festival of new works written by playwrights from historically marginalized identities, and the development of original full-length plays focused on New Mexico-based stories. FUSION is currently working on a play about Blackdom, New Mexico, a town founded in the early twentieth century by African Americans for Blacks fleeing the South's Jim Crow laws. The playwrights and directors of this piece include several direct descendants of the settlers of Blackdom. Another upcoming production, written by a Japanese American playwright, will explore the World War II Japanese internment camps located in New Mexico. Also being developed is a piece written and directed by local Navajo playwrights concerning the impact that COVID-19 has had on the Navajo community in New Mexico. By diversifying their programming, theatre companies can connect with new audiences and expand the demographic breakdown of their audiences. Harrison supports this idea, suggesting that

I think that there's some good that can be done to really ... think about . . . who can we be making theatre for instead of . . . just cater[ing] to really wealthy white people . . . [which] alienates a lot of ... people.... We can't just talk about wanting to bring more diverse groups into our theatre, we actually have to figure out how to do that. And I believe that in order to do that ... we all need to be telling more interesting stories.

This research suggests that theatres can challenge current theatregoers while drawing in different audience demographics by producing new works that connect to their communities.

Forty-five percent of our interviewees expressed a concern that "safe"/traditional ${ }^{8}$ shows would be produced more frequently following the pandemic because theatre producers will be averse to taking artistic risks due to the severe financial impacts of the prolonged closure. Playwright Kate Hamill predicts that "there's going to be a real push to go towards . . . safe programming because [producers are] going to want to ... [produce work] that is going to feel safe to them, [and] make audiences very comfortable, primarily white old audiences." Our interview with dramaturg Lizz Mangar echoed those concerns:

I think theatre also needs to consider what kind of stories they're telling and what voices they're amplifying because the last thing that I want is for theatre to come back and we just get a bunch of revivals of . . . old plays and old shows because I don't really want that right now. I don't [want] plays written by straight white men at the moment. I just don't . . I don't want it right now because it's easy to produce and it's easy to just bring back. ... I want [theatre] to continuously challenge itself when we do come back.

Almost half of our interviewees spoke against a return to "traditional," straight-white-malewritten storytelling; instead, they commented on their hope that producers and artistic directors would choose plays that highlight underrepresented voices and/or new plays that can challenge typical theatregoers and draw in new audiences. Several interviewees stressed how financially successful these types of productions could be. For example, Frank Caeti described a production of Supportive White 
Parents that he directed at Second City Studio Theatre in Los Angeles. The play by Joy Regullano, a Filipina, explored her experience growing up as the daughter of immigrants. According to Caeti, the production surprised his colleagues by bringing in an entirely new audience. He spoke of his excitement when "watching the Asian community come out to see that show because they don't see the [themselves] represent[ed].” This experience taught Caeti that taking artistic risks can benefit the organization, saying, "You can't tell me that people won't come out. They'll come out if they want to, you know? If they can see themselves [onstage] and always if it's a worthwhile story." Telling worthwhile stories can include important messaging for audiences of all demographics.

In addition to wishing for more diverse voices in post-pandemic productions, 51 percent of our interviewees expressed a desire for theatre that empowers communities by connecting with relevant social issues. ${ }^{9}$ Moreover, 70 percent of them expressed a desire for post-pandemic productions that are didactic and encourage audiences to think critically about the world. Artistic director Laura Shatkus expands on this, saying that

\begin{abstract}
the audience is open, more open than people think ... institutions are afraid to challenge their audience ... it's like being a bad teacher. If you assume that your students are stupid, then they will assume so also, and they will proceed as if they are. If you assume that your students are exceptional, then you can raise that, you come up here and they will come up to you. And I think theatres that present conventional, digestible, traditional ... \#boringstuff are not challenging their audiences enough.
\end{abstract}

According to our data, industry professionals from around the country want to see theatres producing more diverse and challenging works when they reopen.

\title{
Increasing Diverse Hiring Practices
}

Ninety-three percent of our interviewees mentioned a vital need to increase the diversity of the professionals working both onstage and off in theatres around the country. The demographic breakdown of our survey respondents is an excellent illustration of the lack of diversity in the industry as a whole. An overwhelming 86 percent of the 553 survey respondents identified as Caucasian. After the murders of George Floyd and Breonna Taylor redrew attention to the Black Lives Matter movement, many predominantly white theatre institutions issued statements in support of it. ${ }^{10}$ However, as David Gordon, a theatre journalist that we interviewed, explained: "all these theatres releasing [Black Lives Matter] statements really need to live up to it when theatre returns and make the changes that they're promising they're going to make. . . I I actually think that will make the theatre industry better. I think it will make the shows better. I think it will make the audiences more engaged." Several of our interviewees noted that one of the issues theatres need to be held accountable for is that of tokenism in the form of a single production by a playwright of color or the hiring of a single BIPOC artist or employee in order to avoid criticism and/or to appear inclusive. Scenic designer Elizabeth Chaney elaborated on this concept, telling us that

I think one of the big problems that was identified is that ... [theatres] choose to do the one "diversity play" and then that's the only time that directors of color and designers of color get work ... and we need to obviously just spread it out and be more open-minded in our casting and, you know, make sure that ... we're hiring designers of color, directors of color to do everything, not just ... the "diversity play."

Twenty-eight percent of our interview respondents agree with Chaney that we need to "be more open-minded in our casting" by increasing the prevalence of colorblind, color-conscious, and nontraditional casting. However, as she also notes, the issue is larger than simply casting decisions. The data from our interviews suggests that theatre professionals believe theatre companies should 
actively seek out diverse individuals when hiring for all positions within their organizations, from trustees and executives to backstage crew. Lighting effects designer and production manager Niomi Collard noted that she is "constantly reminded of [her] otherness by virtue of being . . . the only trans person in production meetings." When she started making hiring decisions, she specifically included a request in job advertisements for people of marginalized identities to apply. "Once I started including that," she told us, "I started getting responses that were more racially diverse, that were more gender diverse." This small change is one way to address the concerns that 30 percent of our interviewees had about finding ways to increase hiring opportunities for women, nonbinary, transgender, and differently abled individuals.

Our qualitative data suggest that rethinking hiring practices is one aspect of a larger issue of diversity in theatre. Half of our interviewees mentioned gatekeeping in educational and internship opportunities, which is linked to larger issues of systemic racism and white privilege. For example, a master electrician we spoke with noted that "white kids are taught to go follow their dreams and ... people of color are taught to go make money." Surviving as a theatre professional requires a web of connections. As interviewees noted, many aspiring professionals from underrepresented groups simply do not have the financial safety net to make connections and jumpstart their careers through low-paying (or unpaid) internships. Fifty percent of our interviewees pointed to this economic gatekeeping as a discriminatory barrier that is preventing many low-income candidates from getting started in the industry. Electrician Michael Bateman stated that

we are our own worst gatekeepers, right? We have these insane barriers to entry ... in the form of unpaid internships ... [and] we have barriers of ridiculously expensive BFA programs ... you have to come from an extremely privileged background in order to gain access. And so, the thing we can do better... [is] reducing and removing those gates and start reaching out to the community.

Making system-wide changes to hiring practices and increasing the diversity of an organization is not easy, but there are companies who have made tangible changes. For example, Frank Mack, the executive producer at Utah Shakespeare Festival, shared with us the new changes in his organization:

[They] include the formation of a committee on diversity and inclusion, sort of a reaffirmation of all of the levels of that work that we've previously been engaged in and need to rededicate ourselves to, which includes further diversifying all parts of our organization, our board, our permanent staff, and our seasonal staff. A commitment to a fifteen dollar minimum wage, which is connected to our ability to attract people of color into all aspects of the organization. And ... [sixteen hours of] diversity training that the entire staff . . . [including] our board, will also undergo.

As many of our respondents noted, this pause due to the pandemic has allowed the industry to examine what it is and what it wants to be. Systemic change is not simple, but perhaps changes made at places like Utah Shakespeare Festival can serve as templates for other theatres around the country to follow.

\section{Conclusion}

There is no denying the reality that many of the hopes for the future of the industry put forth by participants in this study are going to have a financial impact on theatres and organizations. Making tickets more affordable, developing new work, finding ways to transform hiring practices, and breaking down economic barriers for internships will all affect the bottom line. However, this approach can work, even on a commercial scale. The best manifestation of the changes many of our survey and interview participants discussed can be seen in the 2019 Broadway production of 
Jeremy O. Harris's Slave Play. The producers of this show made it a priority to increase audience accessibility, produce a show with important social messaging and challenging subject matter, and provide opportunities for a diverse cast and creative team. ${ }^{11}$

Slave Play can be viewed as a call to theatre producers across the country to redefine the essentials of theatre in the twenty-first century. In many ways, Slave Play is a template for enacting the suggestions of the research participants; it was not only well-received by critics and audiences, but it also garnered twelve Tony nominations - the most a new play has ever received. These changes in the theatre industry can happen if those in power decide to change, but it is also up to theatre professionals to remain vigilant in order to continue pressuring those in power to change.

In the past, the theatre community has pushed for changes to be enacted, but little progress has been made because the passion for change soon fades. This lack of persistence can be a result of many factors. Many theatre professionals literally work from paycheck to paycheck, hence it is risky speaking out when doing so may impact your future employment. A performer in Washington, D.C., that we interviewed acknowledged this dilemma: "You know, on the one hand ... everybody will be afraid to speak out because ... they'll just want to get back to work. [But] people ... [aren't] working now ... [and] when we go back, we're going to go back on our terms." As New York performer Hayley Moir noted, now is the time for change:

What I'm hoping, that this pause and this ... reflection and this just kind of tearing back of a curtain does for the theatre community and the larger community that funds it, is that it shows you all the problems ... and that moving forward, it can be something bigger and better ... it doesn't just have to be back to business as usual. And I don't think it can be. I don't think a lot of people will stand for that.

Sixty percent of our interviewees agree that they want theatre professionals to hold theatres accountable for their promises to end discrimination and oppression and to make their companies more accessible to historically marginalized groups. The data presented here can serve as a call to action for the theatre community to come together to change our industry in positive ways. The voices of the industry's essential workers are vital; now is the time for systemic change, and in order to thrive in a post-pandemic world the industry as a whole must prioritize becoming more accessible and diverse.

Nathan Stith is an assistant professor of theatre at Trinity University in San Antonio, Texas, where he teaches acting, voice and speech, musical theatre performance, and musical theatre history. He is also the artistic director of Oldcastle Theatre Company in Bennington, Vermont. His recent publications include "Interrogating the Musicals We Love: An Argument for Critical Thought" (Musical Theatre Educators Alliance Journal) and chapters in Objectives, Obstacles, and Tactics in Practice: Perspectives on Activating the Actor (2019) and iBroadway: Musical Theatre in the Digital Age (2017). As an actor he has appeared in national tours of Jesus Christ Superstar and Romeo and Juliet as well as regional productions at Arvada Center for the Performing Arts, Colorado Shakespeare Festival, and Riverside Theatre, among others. He holds a PhD in theatre from University of Colorado Boulder.

Aria Gastón-Panthaki is completing her bachelor's degree in psychology with a minor in theatre at Trinity University in 2021. She received the 2020 Mellon Initiative Fellowship in support of her work on this theatre project. Over the past two years she has worked as a research assistant in the Verb Learning Lab and Food Matters Lab, both at Trinity University, as well as the Proyecto Voces Lab at the University of Texas Health San Antonio. 
Rachel Morris is a Baker Duncan Theatre Scholar at Trinity University, completing their degree in May 2021 with a BA in theatre and minors in women and gender studies and sociology. They received a Mellon Initiative Fellowship in 2020 for their work on this theatre project. As a theatre artist, they work primarily as a stage manager, lighting designer, sound designer, and director.

\section{Notes}

1. For this project, we defined professional as an individual who earned income working on a theatrical production of any kind during the past two years.

2. The survey was sent to multiple Facebook groups: What If? What Now? What Next?; Musical Theatre Directors and Producers; My Show Got Canceled Because of a Pandemic and All I Have Is This Void; Denver Area Actors Continuing Education Forum; Musical Theatre Educators Alliance; U.S. Theatre Director Resources; Hofstra Drama and Dance Alumni; Theatre Teacher Conspiracy; Year of the Stage Manager 2020/21; CU Boulder Theatre and Dance Graduate Alumni; Oldcastle Alum.

3. For more information about mixed-method techniques, see Gaganpreet Sharma, "Pros and Cons of Different Sampling Techniques."

4. Along with critics such as Brandi Wilkins Catanese (The Problem of the Color[blind]: Racial Transgression and the Politics of Black Performance), we recognize that these practices are not exactly synonymous. Assessing professionals' understanding and opinions of these practices, however, will require more focused surveys.

5. All interviewees were given the opportunity to consent to the use of their names after completing the interview. If interviewees wished to remain anonymous, their names were redacted.

6. According to a 2019 Theatre Communications Group fiscal survey of 177 professional not-for-profit theatres, the average single ticket price rose from $\$ 29.73$ to $\$ 41.19$ between 2007 and 2018; see S. Lock, "Theater \& Broadway in the U.S."

7. For other examples of creative ticketing strategies, see Main's Penobscot Theatre Company and Round House Theatre in Maryland; see Theresa J. Beckhusen, "Priority Report: Theatre Facts 2016."

8. The authors define "safe"/traditional shows as those productions that reinforce the status quo or are longestablished audience favorites, such as conventionally staged revivals.

9. For example, Theatre of War Productions 2014 and 2020 presentations of Antigone in Ferguson.

10. Many of these statements were also in response to the June 8, 2020 "Statement: We See You, White American Theater" signed by over 300 Black and African American theatre artists, which called out the systemic racism within the industry and created a list of demands for change.

11. For more information about the efforts that Slave Play took to increase accessibility to a diverse audience (racial and economic), see Elizabeth A. Harris and Reggie Ugwu, "Was Broadway Ready for 'Slave Play'?"

\section{Works Cited}

Anonymous. Personal interview with the authors, 15 June 2020

Personal interview with the authors, 23 June 2020. 
—. Personal interview with the authors, 7 July 2020.

Antigone in Ferguson. Theater of War Productions. 2020. Web. 2 Sept. 2020.

Bateman, Michael. Personal interview with the authors, 18 June 2020.

Beckhusen, Theresa J. “Priority Report: Theatre Facts 2016.” American Theatre. 16 Mar. 2018. Web. 18 Aug. 2020.

Blum, Nancy. Personal interview with the authors, 30 June 2020.

Caeti, Frank. Personal interview with the authors, 24 June 2020.

Catanese, Brandi Wilkins. The Problem of the Color[blind]: Racial Transgression and the Politics of Black Performance. Ann Arbor: U of Michigan P, 2011. Print.

Chaney, Elizabeth. Personal interview with the authors, 18 June 2020.

Collard, Niomi. Personal interview with the authors, 29 June 2020.

Gordon, David. Personal interview with the authors, 24 June 2020.

Grey, Joel. “Opinion: Before Coronavirus, Theater Was My Salvation. Where Do I Turn Now?” New York Times. 22 Apr. 2020. Web. 18 May 2020.

Gromelski, Dennis. Personal interview with the authors, 16 June 2020.

Hamill, Kate. Personal interview with the authors, 23 June 2020.

Harris, Elizabeth A., and Reggie Ugwu. "Was Broadway Ready for 'Slave Play'?" New York Times. 27 Jan. 2020. Web. 20 Aug. 2020.

Harrison, Emily. Personal interview with the authors, 18 June 2020.

Jacobs, Julia. "Poll Shows One Hurdle to Reopening Broadway: Fear of Jerks." New York Times. 26 May 2020. Web. 27 May 2020.

Lock, S. “Theater \& Broadway in the U.S.” Statista. 28 Aug. 2018. Web. 2 Sept. 2020.

Lord, Clayton. The Arts Diversity Index: Measurement of and Impacts on Diversity in Bay Area Theatre. Theatre Bay Area, California Arts Council, and California Cultural Data Project. 2013. Web. 1 Sept. 2020.

Mack, Frank. Personal interview with the authors, 18 June 2020.

Mangar, Lizz. Personal interview with the authors, 19 June 2020.

McNulty, Charles. "25 Top Theater Minds Dream the Future: What Will the Post-Pandemic Stage Look Like?" Los Angeles Times. 19 May 2020. Web. 25 May 2020.

Moir, Hayley. Personal interview with the authors, 18 June 2020. 
Paulson, Michael. "Broadway, Symbol of New York Resilience, Shuts Down Amid Virus Threat." New York Times. 12 Mar. 2020. Web. 17 Sept. 2020.

. "The Universe Hit Pause': The Ripple Effects of Broadway's Shutdown." New York Times. 7 May 2020. Web. 18 May 2020.

Sharma, Gaganpreet. "Pros and Cons of Different Sampling Techniques." International Journal of Applied Research 3.7 (2017): 749-52. Print.

Shatkus, Laura. Personal interview with the authors, 16 July 2020.

Soloski, Alexis. "Broadway Adjourns, but the 'Sing Street' Band Plays On.” New York Times. 27 Apr. 2020. Web. 18 May 2020.

“Statement: We See You, White American Theater." 8 June 2020. Web. 1 Sept. 2020.

Stokes, Erin, et al. "Coronavirus Disease 2019 Case Surveillance-United States, January 22-May 30, 2020." Centers for Disease Control and Prevention. 18 June 2020. Web. 18 Aug. 2020.

Thorpe, Vanessa. “It's a terrible time': Why Simon Russell Beale Fears for Future of Theatre." Guardian. Web. 19 Aug. 2020.

Weinert-Kendt, Rob. "Most Theatregoers Won't Come Back Immediately, Studies Show." American Theatre. 11 May 2020. Web. 18 May 2020. 